\title{
The Effect of Work Environment, Work Facilities and Work Motivation on Employee Performance at the DPRD Secretariat Bondowoso Regency
}

\author{
Abdul Wahet ${ }^{1}$, Suwignyo Widagdo ${ }^{2}$, Agustin Hari Prastyowati ${ }^{3}$ \\ Student of STIE Mandala Jember ${ }^{1}$, Lecturer of STIE Mandala Jember ${ }^{2,3}$ \\ Email: abdw9509@gmail.com¹; suwignyo@stie-mandala.ac.id²; agustin@stie-mandala.ac.id²
}

\begin{abstract}
To achieve organizational goals requires a good performance from its employees. Employee performance factors are strongly influenced by the work environment, work facilities and employee motivation. The purpose of this study was to determine how much influence the Work Environment, Work facilities and Work Motivation on Employee Performance in the Secretariat of the Bondowoso Regency DPRD either partially or simultaneously. Respondents in this study were 65 civil servants with civil servant status in the Secretariat of the DPRD Bondowoso Regency as many as 65 people who were determined using saturated sampling techniques, where all populations were sampled. The data analysis used in this study is multiple linear regression analysis to determine the level of influence of the independent variable on the dependent variable with the help of the SPSS for Windows program. The partial test results for the influence of work environment variables on employee performance, it is known that there is a significant influence of work environment on employee performance. For the influence of work facilities variables on employee performance, it is known that there is a significant effect of work facilities on employee performance. And for the influence of work motivation variables on employee performance, it is known that there is a significant effect of work motivation on employee performance. Simultaneous testing results, it can be concluded that the work environment, work facilities, and work motivation are proven to have a significant effect simultaneously on employee performance in the Secretariat of the DPRD Bondowoso Regency.
\end{abstract} Keywords: Work Environment; Work Facilities; Work Motivation; Employee Performance

\section{INTRODUCTION}

Every organization formed by humans has an activity with specific goals. The goals of the organization, adjust to the background and needs of the organization. The achievement of an organization towards these goals as has been made and determined together in one forum, it can be said that the organization is in accordance with planning standards. To achieve organizational 
goals requires a good performance from various parties in an organization including its employees.

Employees are the most important element in determining the back and forth of an organization. To achieve organizational goals requires employees who are in accordance with the requirements in the organization, and must also be able to carry out the tasks that have been determined by the organization. Every organization will always try to improve the performance of its employees, with the hope of achieving organizational goals.

Employee performance is the result of work in quality and quantity achieved by an employee in carrying out his duties in accordance with the responsibilities assigned to him (Mangkunegara, 2009). According to Rivai and Basri (2005), performance is the willingness of a person or group of people to carry out an activity and improve it according to their responsibilities with the expected results. Employee performance is an individual matter, therefore each employee has his own way and ability to carry out tasks and improve his performance.

According to Rivai and Basri (2005), employee performance is influenced by the work environment. Sedarmayanti (2001) explains, the work environment is the entire tooling tool and material faced, the surrounding environment where a person works, his work methods, and work arrangements both as individuals and as a group. From this it can be concluded that a good working environment will support employee productivity which in turn has an impact on employee performance.

Another factor that can affect employee performance is work facilities. Work facilities can be interpreted as anything that can facilitate and facilitate all activities and businesses. According to Lupiyaodi (2006: 34), facilities are a means used to facilitate and facilitate carrying out functions.

Work facility is a means of supporting the activities of a company or organization in physical form, and is used in normal company activities, has a relatively permanent useful life and provides benefits for the future. Work facilities are very important for companies, because they can support employee performance, such as in completing work (Chairun Nisa: 2018).

In addition, work motivation also affects employee performance. As explained by Anoraga (2005), motivation is something that creates enthusiasm or work motivation. Work motivation is the most vital driving force in achieving performance. Without motivation, employees will 
not succeed in completing a job maximally because there is no will that comes from within the employees themselves.

The Regional Representative Council Secretariat of Bondowoso Regency is part of the Bondowoso Regency Government organization which has the task of assisting the duties and functions of members of the Bondowoso Regency DPRD. In order to carry out this task, the Secretariat of the Regional Representative Council of Bondowoso Regency needs human resources who are able to work effectively and efficiently supported by a good working environment, work facilities and work motivation.

Moreover, currently the performance evaluation of employees in the Bondowoso Regency Government, including the Bondowoso Regency DPRD Secretariat is already based on electronic (e-performance) as mandated by Law Number 5 of 2014 concerning State Civil Apparatus article 1 paragraph 6 which reads that the ASN information system is a series of information and data regarding ASN employees that is compiled systematically, thoroughly, and integrated based on technology. This is in accordance with one of the Reform missions of the Ministry of Administrative Reform and Bureaucratic Reform, namely the modernization of the bureaucracy through the use of IT.

e-Kinerja is an application that is used to measure and assess the achievement indicators of Civil Servants (PNS) in order to digitize the personnel work system in a government. The goal is to find out what to do and strive to achieve the performance targets in accordance with the performance standards specified in the Employee Work Goals (SKP).

Within the Bondowoso Regency Government, including at the Bondowoso Regency DPRD Secretariat, this e-performance assessment has been implemented since 2017. However, the indicators used refer to Government Regulation Number 46 of 2011 concerning Civil Servant Job Performance Assessment. Since 2020, the performance assessment of Civil Servants within the Bondowoso Regency Government has begun to implement Government Regulation Number 30 of 2019 concerning Performance Assessment of Civil Servants.

Based on the description above, researchers are interested in conducting a study entitled "The Effect of Work Environment, Work Facilities and Work Motivation on Employee Performance at the Regional Representative Council Secretariat of Bondowoso Regency" 


\section{RESEARCH METHODS}

This research was conducted in Bondowoso Regency, to be precise at the Secretariat of the DPRD Bondowoso Regency, Jalan KHR. As'ad Syamsul Arifin no. 100, Tenggarang, Bondowoso. This research was conducted from May to June 2020.

Population is a generalization area consisting of: objects / subjects that have certain qualities and characteristics (Sugiyono, 2018: 80). The population in this study were 56 Civil Servants (PNS) in the Secretariat of the Bondowoso Regency DPRD.

The sample is part of the number and characteristics of the population (Sugiyono, 2018: 81). The sample used was all populations, namely 56 civil servants. If all members of the population are used as samples, it is called saturated sampling or other terms census (Sugiyono, 2018: 85). This research uses explanatory research with a quantitative approach. Mohamad Dimyati (2019: 36) explains explanatory research aims to explain the relationship between variables through hypothesis testing. While the data collection methods used in this study are questionnaires, interviews, observation and documentation.

\section{Data Analysis Method}

\section{A. Test Instruments}

In quantitative research, the main criteria for research results are valid, reliable and objective (Sugiono, 2018: 267). So to get valid and reliable data that is tested for validity and reliability is the research instrument (Sugiono, 2018: 268).

\section{Validity Test}

The validity test in this study was carried out by using Pearson Validity correlation with the product moment technique, namely the score of each item was correlated with the total score. The validity of an instrument item is obtained from the results between the items that are correlated with the total score then compared with the critical value $r$ listed at the bottom of the critical value. If the correlation value of each question item is greater than the critical value $r$ or the significance value is less than 5\% (level of significance) then the item is said to be valid (Arikunto, 2010: 211).

\section{Reliability Test}

Sugiyono (2018: 121) says that a reliable instrument is an instrument that when used several times to measure the same object will produce the same data. Every measuring device should have the ability to provide consistent measurement results. To test the reliability of the 
questionnaire used, a reliability analysis was carried out based on the Cronbach Alpha $(\alpha)$ coefficient. Indicators are accepted if the Cronbach Alpha $(\alpha)$ coefficient is above 0.60 (Sugiyono in Sisardi, 2016: 42).

\section{Classic Assumption Test}

\section{Normality Test}

Singgih Santoso (2017: 42) states that the Normality Test aims to determine whether the distribution of a data follows or approaches the normal distribution, namely the bell-shaped data distribution. Singgih Santoso continued that "good" data is data that has a normal distribution pattern, namely the distribution is not skewed to the left or to the right. The way to test for normality is to look at the distribution of the points on the diagonal axis of the graph. The basis for decision making according to Ghozali (2016: 105), are:

1. If the points spread around the diagonal line and follow the direction of the diagonal line, the regression model satisfies the assumption of normality.

2. If the point spreads far from the diagonal line and / or does not follow the direction of the diagonal line, the regression model does not meet the assumption of normality.

\section{Multicollinearity Test}

The multicollinearity test aims to test whether there is a high or perfect correlation between the independent variables (Siswanto and Suyanto, 2018: 193). If there is a correlation, then there is a multicollinearity problem. A good regression model should not have a correlation between the independent variables. Symptoms of multicollinearity can also be detected by using the VIF (Variance Inflation Factor) value obtained using the SPSS program, namely multicollinearity occurs when the VIF value approaches 10.

\section{Heteroscedasticity Test}

One of the methods used to detect whether or not heteroscedasticity is present is by looking at the plot graph between the value of the dependent variable and its residual. The basis of the analysis used according to Ghozali (2016: 139), is:

a. If there is a certain pattern, such as the points that exist to form a certain regular pattern (wavy, widened, then narrowed), then there has been heteroscedasticity.

b. If there is no clear pattern and the dots spread above and below the 0 on the $\mathrm{Y}$ axis, there is no heteroscedasticity. 


\section{Multiple Linear Regression Analysis}

This study uses multiple linear regression analysis which is used to determine how much is the trend or tendency of independent variables (independent), namely Work Environment (X1), Work Facilities (X2) and Work Motivation (X3) on the dependent variable (denpenden), namely Employee Performance Y). Siswanto and Suyatno (2018: 187) formulate Multiple Linear Regression as follows: $\mathrm{Y}=\mathrm{a}+\mathrm{bX} 1+\mathrm{bX} 2+\mathrm{bX} 3$

Description :

$\mathrm{Y}=$ dependent variable

$\mathrm{a}=$ constant

$\mathrm{b}=$ regression coefficient

$\mathrm{X} 1=$ the first independent variable

$\mathrm{X} 2=$ second independent variable

X3 = third independent variable

\section{Hypothesis Testing}

\section{A. Partial Significance Test (t Statistical Test)}

The $\mathrm{t}$ statistical test aims to determine how much influence one independent variable individually (partially) has in explaining the variation of the dependent variable (Ghozali., 2016). With the level of significance or the level of significance ( $\alpha$ ) $5 \%$. The test criteria for the t statistical test are:

1. If the value of $t$ count $\geq t$ table, then $H 1$ is accepted or one independent variable partially affects the dependent variable.

2. If the value of $\mathrm{t}$ count $<\mathrm{t}$ table, then $\mathrm{H} 1$ is rejected or a partially independent variable has no effect on the dependent variable

\section{B. Simultaneous Significance Test (Test Statistic F)}

According to Ghozali (2016), the F statistical test is used to find out whether all the independent variables that are included in the model affect jointly (simultaneously) on the dependent variable. With a level of significance $(\alpha) 5 \%$, the test criteria for the F Statistical Test is if the calculated $\mathrm{F}$ value is greater than the $\mathrm{F}$ table value, then all independent variables are Work Environment (X1), Work Facilities (X2) and Work Motivation (X3) simultaneously affects the dependent variable, namely Employee Performance (Y). 


\section{Coefficient of Determination (R2)}

The coefficient of determination (R2) is the magnitude of the relationship / influence of the independent variables together on the dependent variable in the form of a percentage (\%) (Siswanto and Suyanto, 2018: 187). The coefficient of determination is between zero and one. If the value of $\mathrm{R} 2$ is small, it means that the ability of the independent variable to explain the dependent variable is very limited. Meanwhile, if the R2 value is close to one, it means that the independent variable provides almost all the information needed to predict the dependent variable (Ghozali, 2016).

\section{RESULT AND DISCUSSION}

4.1 Analysis of Research Results

\section{A. Test Instruments}

1. Validity Test

Based on the validity test using the SPSS for Windows program package, the results show that independent variables, namely Work Environment, Work Facilities and Work Motivation and the dependent variable, namely Employee Performance, are declared valid with a probability value (significance) $\mathrm{r}$ count less than $5 \%(0.05)$. ). This means that the indicators used in this research variable are feasible or valid to be used as data collectors.

\section{Reliability Test}

The results of reliability testing are as follows:

Table 1 Reliability Test Results

\begin{tabular}{cccc}
\hline No & Variable & Cronbach Alpha $(\boldsymbol{\alpha})$ & Description \\
\hline 1 & $\mathrm{X}_{1}$ & 0,778 & \\
2 & $\mathrm{X}_{2}$ & 0,652 & Reliabel \\
3 & $\mathrm{X}_{3}$ & 0,791 & $\alpha>0,6$ \\
4 & $\mathrm{Y}$ & 0,766 & \\
\hline
\end{tabular}

Based on Table 1, it can be concluded that all variables used in this study are reliable, because they have a Cronbach Alpha $(\alpha)$ value greater than 0.60 . As required by Sugiyono (2018: 268) that the variable is said to be reliable if it provides a Cronbach Alpha value> 0.6 . 


\section{Classic Assumption Test}

\section{Normality Test}
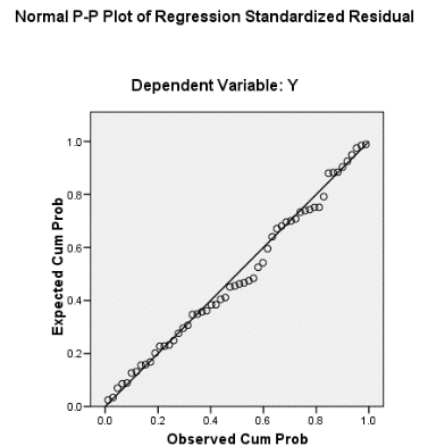

Figure 1 Normality Test Results

Source: Output SPSS, 2019

Based on Figure 1, it is known that the graph of the normality test results against the regression model, there are points spreading around the diagonal line, and the distribution follows the direction of the diagonal line. Then the regression model is suitable for use because it has met the normality assumption

2. Multicollinearity Test

Table 2 Collinearity Statistic

\begin{tabular}{ccc}
\hline Variabel & VIF & Keterangan \\
\hline $\mathrm{X}_{1}$ & 1,190 & Tidak ada multikolinearitas \\
$\mathrm{X}_{2}$ & 1,039 & Tidak ada multikolinearitas \\
$\mathrm{X}_{3}$ & 1,204 & Tidak ada multikolinearitas \\
\hline
\end{tabular}

Source: Output SPSS, 2019

Based on the results of the Collinearity Statistic analysis, it is known that there is no multicollinearity in the model. This can be seen in appendix 6 where the VIF value of each variable is less than 5 . 


\section{Heteroscedasticity Test}

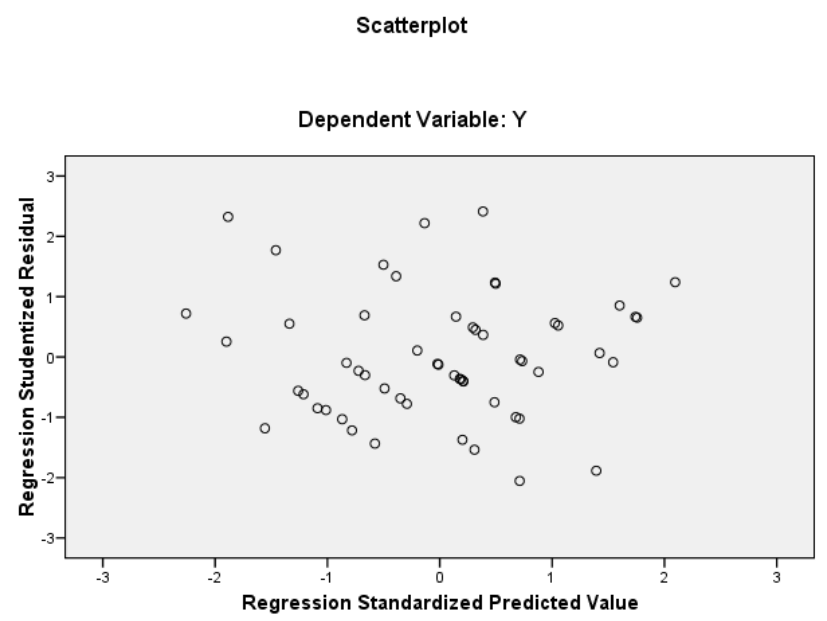

Figure 2 Heteroscedasticity Test Results Source: Output SPSS, 2019

The results of the analysis of the scatterplots graph in Figure 2 show that the points spread randomly, do not form a certain clear pattern, and are spread either above or below the number 0 on the $\mathrm{Y}$ axis.

\section{Results of Multiple Linear Regression Analysis}

Based on testing with the help of the SPSS for Windows program, results are obtained which can be presented in the following table

Table 3: Multiple Linear Regression Calculation Results

\begin{tabular}{ccccc}
\hline Variable & Koef. Regresi & $\mathbf{t}_{\text {hitung }}$ & Sig. & Description \\
\hline Konstanta & $-3,671$ & $-1,328$ & 0,190 & - \\
$X 1$ & 0,232 & 4,327 & 0,000 & Signifikan \\
$X 2$ & 0,208 & 3,403 & 0,001 & Signifikan \\
$X 3$ & 0,213 & 4,109 & 0,000 & Signifikan \\
\hline & & R Square & $=$ & 0,611 \\
& & Adj. $R$ Square & $=$ & 0,588 \\
& & Fhitung & $=$ & 27,190 \\
& & Sig. F & $=$ & 0,000 \\
& & N & $=56$ \\
& & t tabel & $=$ & 2,018 \\
& & F table & $=$ & 2,830 \\
\hline
\end{tabular}

Source: Output SPSS, 2019 
Description:

X1: Work Environment

X2: Work Facilities

X3: Work Motivation

Based on Table 3, the regression equation is obtained as follows:

$\mathrm{Y}=-3.671+0.232 \mathrm{X} 1+0.208 \mathrm{X} 2+0.213 \mathrm{X} 3$

The interpretations of this equation are as follows

1. A constant value of -3.671 , indicating the magnitude of employee performance (Y) when the work environment variable is not representative, work facilities are not supportive, and employee motivation is low. This shows that the performance of employees at the Secretariat of the Regional People's Representative Council of Bondowoso Regency has a negative value which means that it will decrease due to other factors outside the model under study.

2. The regression coefficient $\mathrm{X} 1=0.232$, meaning that if work facilities and work motivation are considered constant, the better the work environment (X1) will lead to better employee performance (Y) at the Regional Representative Council Secretariat of Bondowoso Regency.

3. The regression coefficient $\mathrm{X} 2=0.208$, meaning that if the work environment and work motivation are considered constant, the better work facilities (X2) will lead to better employee performance (Y) at the Regional Representative Council Secretariat of Bondowoso Regency.

4. The regression coefficient $\mathrm{X} 2=0.213$, meaning that if the work environment and work facilities are considered constant, the better work motivation (X3) will lead to better employee performance (Y) at the Regional Representative Council Secretariat of Bondowoso Regency.

\subsection{Hypothesis Testing}

A. Partial Testing (t statistical test)

Table 4. $\mathrm{t}$ test results

\begin{tabular}{lcccl}
\hline \multicolumn{1}{c}{ Variabel } & thitung & ttabel & Sig. & Keterangan \\
\hline Lingkungan Kerja & 4,327 & 2,018 & 0,000 & Signifikan \\
Fasilitas Kerja & 3,403 & 2,018 & 0,001 & Signifikan \\
Motivasi Kerja & 4,109 & 2,018 & 0,000 & Signifikan
\end{tabular}

Source: Output SPSS, 2019 
The results of t-test calculations using the SPSS for Windows program can be seen in Table 4.Based on this table, it can be seen that the influence of each independent variable on the dependent variable is as follows:

1. Effect of work environment variables (X1) on employee performance (Y)

The test results for the influence of work environment variables (X1) on employee performance (Y) obtained t count of 4.327 and is greater than t table (4.327> 2.018) and a significance value $<\alpha(0.000<0.05)$. Because the probability level is less than $5 \%$, then $\mathrm{H} 0$ is rejected, meaning that partially the work environment variable has a significant influence on employee performance. Thus, the hypothesis which states that there is an influence of the work environment on employee performance in the Secretariat of the DPRD Bondowoso Regency is proven (Hᄀ1.1 accepted).

2. The influence of work facility variables (X2) on employee performance (Y)

The test results for the influence of the work facility variable (X2) on employee performance (Y) obtained t count of 3.403 and greater than $t$ table $(3.403>2.018)$ and a significance value $<\alpha(0.001<0.05)$. Because the probability level is less than $5 \%$, then $\mathrm{H} 0$ is rejected, meaning that partially the work facility variable has a significant effect on employee performance. Thus, the hypothesis which states that there is an effect of Work Facilities on employee performance in the Secretariat of the DPRD Bondowoso Regency is proven ( $\mathrm{H} \neg 1.2$ accepted).

3. The effect of work motivation (X3) on employee performance (Y)

The test results for the influence of the work motivation variable (X3) on employee performance (Y) obtained t count of 4.109 and is greater than $t$ table (4.109> 2.018) and a significance value $<\alpha(0.000<0.05)$. Because the probability level is less than $5 \%$, then $\mathrm{H} 0$ is rejected, meaning that partially work motivation variables have a significant effect on employee performance. Thus, the hypothesis which states that there is an influence of work motivation on employee performance in the Secretariat of the DPRD Bondowoso Regency is proven to be true (H1.3 is accepted).

B. Simultaneous Testing (F statistical test)

Based on Table 4 it can be seen that the calculated $F$ value of 27.190 is greater than the $F$ table $(27.190>2.830)$ and the probability value (Pvalue) $<0.05$ or $(0.000<0.05)$ it can be stated that the work environment, work facilities, and motivation work proved to have a significant effect simultaneously on employee performance. Thus, the hypothesis which states that 
simultaneously there is an influence of the Work Environment, Work Facilities and Work Motivation on Employee Performance in the Secretariat of the Bondowoso Regency DPRD is proven to be true or $\mathrm{H} 2$ is accepted.

\section{Multiple Determination Coefficient (R2)}

Based on the results of the analysis which can be seen in Table 4, the adjusted coefficient of determination (Adjusted R2) is 0.588 , this means that $58.8 \%$ of variations in employee performance changes can be explained by variables of work environment, work facilities, and work motivation. While the remaining $41.2 \%$ was caused by other factors that were not included in the regression equation made. According to Sholikin, these other factors could be such as the style of communication of DPRD leaders and members, performance allowances or employee income allowances (TPP), and others related to the performance of civil servants.

\subsection{Discussion}

\section{A. Effect of Work Environment on Employee Performance}

The results showed that the work environment had a positive and significant effect on employee performance with a coefficient of 0.232 . This means that the work environment factor as measured by the color of the walls in the employee's workspace supports the employee's state of mind for work, the existing lighting (sunlight and electricity) in the work space is in accordance with the needs, the air condition in the work space provides comfort to employees while working., the work environment of employees is calm and free from engine noise, the space for movement in the work space has provided flexibility to employees, there are security officers in the office environment, making workers work very well, cleanliness in the work place of employees makes employees comfortable, every employee has responsibilities in accordance with their duties Each employee has a clear work structure as well as their rank and position, the relationship between colleagues is very harmonious, and good communication between colleagues, superiors and subordinates is a factor that determines the performance of employees in the Secretariat of the DPRD Bondowoso Regency.

Most of the employees in the Secretariat of the Bondowoso Regency DPRD have a fairly high educational background, which means that they have good enough competence and are supported by a conducive working environment, which is certainly expected to encourage the achievement of optimal performance. On the other hand, the characteristics of the productive age possessed by civil servants at the Regional Representative Council Secretariat of 
Bondowoso Regency are another supporting factor of the real influence of the work environment on performance. Civil servants at the Secretariat of the Regional People's Representative Council of Bondowoso Regency generally give positive assessments of work environment indicators.

Working in a pleasant work environment is the hope and dream of every worker. According to Sedarmayanti (2009: 21) the work environment can affect the work performed by employees. So that every organization or company must strive so that the work environment where employees are always in good condition. The work environment affects employee performance which according to Sedarmayanti (2009: 21) that the work environment is a series of things from the environment that are perceived by people who work in an organizational environment and have a big role in directing employee behavior. That is, how employees feel that their work environment is good or bad, pleasant or unpleasant, supportive or even a pressure, depending on how employees will view, interpret and give meaning to something that happens in their work environment, both physical conditions and company conditions and relationships. interpersonal therein. Furthermore, this perception will affect the employee's behavior. So in conclusion, if the company is able to create a comfortable work environment for employees, then employees will feel at home in working without any distraction and pressure, so that employee performance will increase and the goals of the company will be maximally achieved. B. Effect of Work Facilities on Employee Performance

The results showed that work facilities had a positive and significant effect on employee performance with a coefficient of 0.208 . This means that the work facility factor is measured through all work facilities in accordance with the needs of employees, all work facilities are able to optimize work results, all work facilities are very easy to use, all work facilities are very capable of accelerating the work process, and all work facilities are arranged and placed very accordingly. with need is a factor that determines the performance of employees in the Secretariat of the Bondowoso Regency DPRD.

Based on the description, the employees in the Secretariat of the Bondowoso Regency DPRD consist of several levels ranging from staff to leadership. Of course, they require different work facilities but all of them must be able to support increased performance. In addition, the level of education of an employee will require the fulfillment of work facilities in accordance with the workload. Referring to these conditions, agencies must be able to provide adequate work 
facilities capable of supporting the needs of employees, and in the end this will support employee performance improvements.

Employees at the Regional Representative Council Secretariat of Bondowoso Regency generally give positive assessments of the work facility indicators. The highest assessment is given to the indicator that all work facilities are able to accelerate the work process and all work facilities are able to optimize work results. These two indicators, of course, are considered good and have met employees' expectations, so that their existence must be maintained and maintained. The lowest rating is given to all work facilities here which are easy to use and all work facilities here are in accordance with the needs of employees. Both of these indicators need attention and efforts must be made to improve, so as to support employee performance. As explained by the Secretary of the Bondowoso Regency DPRD regarding the work facilities at the Bondowoso Regency DPRD Secretraiat, the facilities for employees must be able to improve employee performance because the government provides these facilities to support and improve performance. Moreover, the Bondowoso Regency DPRD secretariat has the task of supporting the main tasks and functions of the DPRD.

\section{The Influence of Work Motivation on Employee Performance}

The results showed that work motivation has a positive and significant effect on employee performance with a coefficient of 0.213 . This means that the work motivation factor measured from the salary / income as a civil servant has motivated employees to work, the attitude of the leadership can motivate me to work, becoming a civil servant is increasingly challenging, encourages thinking and doing, and allows meaningful activities, being a civil servant is a calling. soul, and must be implemented with full dedication, being a civil servant can make skills and skills better, get the opportunity and to take part in education and training to support promotion and position as civil servants, awards / praise from the leadership if the results are satisfactory, get recognition from friends work colleagues, feel satisfied with the work achievements that have been achieved so far, the salary and benefits as civil servants have met the economic needs of the family, being a civil servant has made his life happy / happy is a factor that determines the performance of employees in the Secretariat of the DPRD Bondowoso Regency.

Employee backgrounds, whether in age, gender, education, or position, of course, have different motivational factors. There are employees who are motivated by aspects of salary / incentives, 
promotion of positions, proper facilities, and so on. So the agency must be able to encourage the motivation of employees with the aim of improving employee performance. Aspects of motivation in general get a positive assessment from civil servants in the Secretariat Environment Bondowoso Regency DPRD.

Employees have reasons that drive why they want to do certain types of work or activities, why an employee works harder, while other employees work normally. According to Timpe (2010: 59), the key element in work improvement is motivation. According to Hasibuan (2009: 92), motivation is important because with motivation it is hoped that every employee will work hard and be enthusiastic to achieve high performance. Siagian (2008: 287), argues that with the right motivation, employees will be motivated to do as much as possible in carrying out their duties, because they believe that with the success of the company achieving its goals, the interests of employees will also be maintained.

D. The Effect of Work Environment, Work Facilities, and Work Motivation on Employee Performance

The results of the study prove that the work environment, work facilities, and work motivation are proven to have a significant effect simultaneously on employee performance. Thus, the hypothesis which states that simultaneously there is an influence of the Work Environment, Work Facilities and Work Motivation on Employee Performance in the Secretariat of the Bondowoso Regency DPRD is proven to be true or $\mathrm{H} 2$ is accepted.

\section{CONCLUSION}

Based on the descriptions that have been disclosed in the discussion, several conclusions can be drawn as answers to the main problems raised in this study, namely:

The work environment affects the work performance of employees in the Regional Representative Council Secretariat of Bondowoso Regency. Therefore, by paying attention to and providing a comfortable environment for employees, the performance of employees will be better.

Work facilities affect the work performance of employees in the Secretariat of the Regional Representatives Council of Bondowoso Regency. Work facilities to support performance, especially digital work facilities, should be able to keep up with technological developments. Non-digital work facilities also need attention, especially in maintenance. 
Work motivation affects the work performance of employees in the Regional Representative Council Secretariat of Bondowoso Regency. DPRD leaders and members should be able to motivate PNS-PNS at the Bondowoso Regency DPRD Secretariat to be able to improve performance in order to assist the DPRD's duties and functions..

\section{REFERENCES}

Anoraga, Panji, 2006, Psikologi Kerja. Jakarta : PT. Rineka Cipta

Arikunto, Suharsimi, 2013, Prosedur Penelitian. Jakarta : PT. Rineka Cipta

Arikunto, Suharsimi, 2002, Prosedur Penelitian Satu Pendekatan Praktik (Edisi 5). Jakarta : Rineka Cipta.

CHR. Jimmy L. Gaol, 2014, Human Capital Manajemen Sumber Daya Manusia, Jakarta : Gramedia

Dimyati, Mohamad, 2019. Metodologi Riset Pemasaran. Jakarta : Mitra Wacana Media

Ghozali, Imam, 2016, Aplikasi Analisis Multivariate dengan Program IBM SPSS 23, Semarang : BPFE Universitas Diponegoro,

Hasibuan, Malayu S.P, 2009. Manajemen Sumber Daya Manusia (Edisi revisi cetakan ke tiga belas). Jakarta: PT Bumi Aksara.

Iriana, Fristiana, 2017. Metode Penelitian Terapan. Yogyakarta: Parama Ilmu.

Lupiyoadi, Rambat. 2006. Manajemen Sumber Daya Manusia. Jakarta: Bumi Aksara.

Mangkunegara, Anwar Prabu, 2005, Perilaku \& Budaya Organisasi. Bandung: PT Rafika Aditama.

Mangkunegara, Anwar Prabu, 2009, Evaluasi Kinerja SDM. Bandung : PT. Remaja Rosda Karya.

Mangkunegara, Anwar Prabu, 2006. Perencanaan dan. Pengembangan Manajemen Sumber Daya Manusia. Jakarta: PT Refika Aditama.

Moekijat, 2002, Manajemen Tenaga Kerja Dan Hubungan Kerja. Bandung: CV Pionir Jaya.

Moekijat. 2010. Manajemen Sumber Daya Manusia. Cetakan Kesembilan. Bandung: Penerbit Mandar Maju.

Nitisemito, Alex S, 2002, Manajemen Personalia. Jakarta: Ghalia Indonesia.

Pasolong, Harbani, 2011. Teori Administrasi Publik. Bandung : Alfabeta 
Rivai, Veithzal dan Basri, 2005. Performancer Appraisal: Sistem Yang Tepat Untuk Menilai Kinerja Karyawa dan Meningkatkan Daya Saing Perusahaan. Jakarta : PT. Raja Grafindo Persada

Santoso, Singgih, 2017. Statistik Multivariat Dengan SPSS. Jakarta : Gramedia

Sayuti, 2007, Motivasi \& Faktor-Faktor yang Mempengaruhi. Jakarta: Penerbit Ghalia Indonesia.

Sedarmayanti, Putri, 2001. Manajemen Perkantoran Modern. Bandung: Mandar Maju

Sedarmayanti, Putri, 2001. Sumber Daya Manusia dan Produktivitas Kerja. Bandung: Mandar Maju.

Sedarmayanti, Putri, 2007, Manajemen Sumber Daya Manusia. Jakarta: PT Bumi Aksara

Sedarmayanthi. Putri. 2009. Manajemen Sumber Daya Manusia Reformasi Birokrasi dan Manajemen Karyawan Negeri Sipil Bandung: PT. Refika Aditama.

Siagian, Sondang., P. 2008. Manajemen Sumber Daya Manusia (Edisi. Pertama). Jakarta: Binapura Aksara.

Siswanto dan Suyanto, 2018. Metode Penelitian Kuntitatif Korelasional. Klaten : BOSSSCRIPT

Sugiyono, 2018, Metode Penelitian (Kuantitatif, Kualitatif dan $R \& D$ ), Bandung: Alfabeta Sugiyono, 2016, Metode Penelitian Kualitatif. Bandung: Alfabeta

Widagdo, Suwignyo, 2017. Manajemen Sumber Daya Manusia. Jember : Mandala Press

Yusuf Hamali, Arif, 2018, Pemahaman Manajemen Sumber Daya Manusia. Cetakan ketiga. Yogyakarta : CAPS 